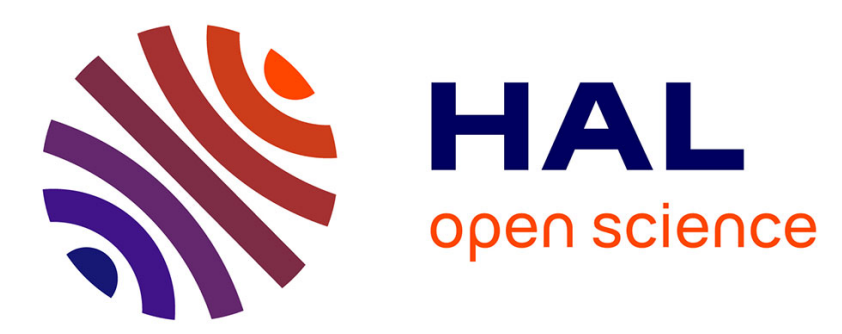

\title{
Transient and modulation dynamics of an erbium fiber laser
}

\author{
E. Lacot, F. Stoeckel, M. Chenevier
}

\section{To cite this version:}

E. Lacot, F. Stoeckel, M. Chenevier. Transient and modulation dynamics of an erbium fiber laser. Journal de Physique IV Proceedings, 1994, 04 (C4), pp.C4-597-C4-597. 10.1051/jp4:19944148 . jpa00252603

\section{HAL Id: jpa-00252603 https://hal.science/jpa-00252603}

Submitted on 1 Jan 1994

HAL is a multi-disciplinary open access archive for the deposit and dissemination of scientific research documents, whether they are published or not. The documents may come from teaching and research institutions in France or abroad, or from public or private research centers.
L'archive ouverte pluridisciplinaire HAL, est destinée au dépôt et à la diffusion de documents scientifiques de niveau recherche, publiés ou non, émanant des établissements d'enseignement et de recherche français ou étrangers, des laboratoires publics ou privés. 


\title{
Transient and modulation dynamics of an erbium fiber laser
}

\author{
E. LACOT, F. STOECKEL and M. CHENEVIER
}

Laboratoire de Spectrométrie Physique, associé au CNRS, BP. 87, Université Joseph Fourier, 38402 Saint Martin d'Hères cedex, France

The temporal dynamics, in the transient regime and under pump modulation, has been investigated experimentally and theoretically.

Experimentally it was observed that an erbium doped fiber laser oscillates on two orthogonal polarisations. In the transient regime, the two polarisations exhibit oscillations with a superposition of two frequencies, while the total intensity oscillates only with the highest frequency.

In the stationary regime, behaviour of the fiber laser going from a cw working mode to a self pulsed mode, is observed by increasing the pump power.

In response to a periodic modulation of the pump power, here a krypton ionised laser, the fiber laser produces near the two eigenfrequencies, a subharmonic sequence leading to the chaos.

In a cw mode, a parametric study is given versus the output coupling, the length of the cavity and the concentration of the dopant. In self pulsed mode the variation of the oscillation frequency with different parameters is reported. Physical parameters of these observations are determined.

A theoretical model, based on two coupled lasers coherently pumped is proposed. A linear stability analysis is given which demonstrates the existence of a transition between a cw and a self pulsed working mode (Hopf bifurcation) for a low value of the pump parameter. A numerical simulation based on the proposed model describes qualitatively all the observed phenomena.

[1] E. LACOT Thèse Université J. Fourier, Grenoble 1992

[2] E. LACOT, F. STOECKEL, M. CHENEVIER, Dynamics of an Erbium doped fiber laser. To be published. 